\title{
How does inquiry-based instruction affect learning in a secondary school Science class?
}

\begin{abstract}
This study used a quasi-experiment with pretest-post-test design (quantitative) to compare thinking skills achievement tests of students who practise structured-inquiry-laboratory practices (St-IQL) and students who only receive classroom teaching (CT) using two biology chapters in secondary schools. Two classes of Form 4 students $(n=64)$ from two public secondary mixed schools in Kuala Lumpur, Malaysia, were selected for the study. Higher and lower order thinking skills questionnaires (suggested by Bloom) were handed out in the pretest and post-test. The post-test was administered after both classes had done the treatments, respectively ( 8 weeks), in order to evaluate the level of students' thinking skills of biology concepts. The students who were exposed to St-IQL treatment achieved higher post-test mean scores than those who were exposed to CT method. A small effect size (partial eta squared) of 0.23 suggests that $23 \%$ of the variance in the post-test scores was related to the differences in the instructional methods.
\end{abstract}

Keyword: Biology; Constructivism; Inquiry; Laboratory; Practical; Science 